\title{
Partisanship in Crisis: Public Response to Covid-19 Pandemic in Indonesia
}

\author{
Arya Budi ${ }^{1}$, Warih Aji Pamungkas ${ }^{2}$ \\ ${ }^{1}$ Department of Politics and Government, Universitas Gadjah Mada, and \\ Department of Political Science, University of Illinois at Urbana-Champaign \\ (email: aryabudi@ugm.ac.id and abudi2@illinois.edu) \\ ${ }^{2}$ Laboratory of Big Data Analytics, Department of Politics and Government, Universitas Gadjah Mada \\ (email: warih.aji.p@mail.ugm.ac.id)
}

\begin{abstract}
Given the fact that in a context of crises, people are concerned with their safety, among other things, partisan response toward policies and public leaders is an intriguing topic. This article examines the extent to which partisanship pertains to the time of the Covid-19 pandemic. We employ natural language processing (NLP) and social network analysis (SNA) on Twitter data to analyse public responses toward prominent political leaders, namely, Indonesian President Joko Widodo (Jokowi) and Jakarta Governor Anies Baswedan (Anies), in handling the crisis of the Covid-19 pandemic in Indonesia. We then put the social media analysis in a framework of political partisanship. Our sentiment analysis through NLP across time and categories found that supports and demands towards the two public figures indicate positive and negative partisanship that replicates previous electoral supports. Similarly, our SNA indicates a high polarization rate among the accounts connected with the two leaders in response to the crisis. Extended analysis of the accounts who are at the epicentres of the sentiment conversations, either positive or negative about Jokowi and Anies, reveals that there are connections with their past political support. Though we find negative partisan responses for both leaders, a type of hard-core partisanship has been leveraged for Jokowi but not for Anies. We conclude that electoral polarization contributes to the extent to which partisanship responses circulate in a context of crisis.
\end{abstract}

\section{Keywords:}

partisanship; polarization; covid-19; twitter; Indonesia

\section{Introduction}

A group protesting against the stay-athome order regarding the Covid-19 pandemic erupted in Michigan, United States of America, on April 15, 2020. News reports and social media posts around the globe, hereafter, portrayed a series of similar demonstrations in other places in the United States of America. Further news investigation reveals that the sympathizers of Donald Trump were behind the protests (see, for instance, Reid, 2020). Partisanship response in a context of crisis-a situation where people were concerned with their safety, among other things-is an intriguing fact. As Page and Shapiro (1983) suggested a long time ago that "public opinion is often a proximate cause of policy, affecting policy more than policy influences opinion", it is imperative to systematically investigate further in other places with particular contexts. To what extent does partisanship occur and circulate in the context of crisis? How do such partisan responses shape the whole response during the crisis of the Covid-19 pandemic? And what is the explanation(s) of such partisan responses?

Related to these questions, we seek to investigate partisanship in Indonesian contexts, 
one of the most significant new democracies with electoral polarization in the last two elections (see Arifianto, 2019). In doing so, we employed natural language processing (NLP) and social network analysis (SNA) on Twitter from March to April 2020 to analyse responses toward two leaders, the Indonesian president Joko Widodo, later written as Jokowi and the governor of Indonesian capital of Jakarta Anies Baswedan, later written as Anies, in handling the crisis of Covid-19. We contend that electoral polarization contributes to the extent to which partisanship responses circulate in a crisis context. Applying NLP to analyse the pattern of conversation frequencies across time (time series analysis) and categories (clustered analysis), our findings suggest that supports and demand towards the two public figures indicate positive and negative partisanship that replicates previous electoral supports. Similarly, our SNA indicates a high degree of polarization among the thousands of accounts connected with the two leaders in response to the crisis. Extended analyses of the accounts who are the epicentres of the sentiment conversations, either positive or negative about Jokowi and Anies reveal that there are connections with their past political support.

This argument challenges 'conventional' rational-economic arguments on public response where analyses are mainly based on researchers' designed questions or studies in normal realms. Related to debates on literature about public responses, similar to what Page and Shapiro (1983) argue, there is a body of literature suggesting that there is an interconnection between public response and public policy such as the relationship between public preferences and public expenditure (see Soroka \& Wlezien, 2005). Some suggest that elites' behaviour determine how citizens respond to a policy and how public opinion then is circulated (Wlezien, 2004). Yet, there has been a debate about how strong public response affects public policy, and vice versa, how strong elites and policies influence public opinion (Burstein, 2010).

How is public response related to partisanship? It has been academically recognized that elite polarization strengthens public partisanship and, in turn, affects the way citizens respond to information, and, especially, policies (see Bullock, 2009; Druckman et al., 2013). Others suggest that partisan supports on presidential policies, in some extent, are explained by party identification such as Republicans and Democrats in the US (see Foster \& Palmer, 2006). Nevertheless, the extent to which partisanship influences public responses in a context of crisis, a condition when a large majority of people are supposed to rationally consider their safety first among other things, is puzzling.

Partisanship in social media is fairly often regarded as participation. Some studies have investigated and determined that political participation is prevalent in the social media. This participation, accordingly, means that all citizens are actively engaged in conversation of public concern. In some cases, internet activities tend to create polarization regarding the pros and cons of a political figure or a policy. Others suggest that this is not the public, but the platform that creates such polarization (Jacobson et al., 2016; Lee et al., 2018). In the Indonesian context, partisanship is one of the most plausible explanations for voters' digital behaviour in Indonesia (see, for example, Parahita, 2019). In the case of recent analyses about Covid-19's public response on Twitter, some display descriptive data about the content of tweets (see, for example, Hosseini et al., 2020).

To explain our argument, we divide this article into three main sections. The first section will be devoted to settling concepts and frameworks on partisanship and the nature of social media. This section is followed by a portrayal of political polarization in Indonesia as a background of the argument. The methods 
that we apply will be explained in the third part. Followed by a conclusion, the fourth section discusses the findings and arguments in an Indonesian context of electorally polarized polity.

\section{Partisanship and Social Media Platform, a Conjuncture}

Though Campbell et al.'s propositions in The American Voter, a pioneering work in the psychological approach of voting behaviour studies known as the Michigan school, was originated with a notion of strong party alignment as an explainer for voting behaviour, they define partisanship as not merely an identification of individuals towards a political party. In a broader fashion, they define partisanship as "an individual's affective orientation toward an important group object in his environment" (Campbell in Odegard, 1960). For decades, vast scholarships on partisanship have followed the path of such a pioneering definition (see, for instance, Bartels, 2000; J. Bullock et al., 2013; Goren, 2005; Graham \& Svolik, 2020). Drawing on this conceptual understanding and modifying Goren's (2005) conceptual interpretation of the Campbell et al.'s definition, we put leaderbased partisanship here as an individual's affective orientation or attachment to a political leader, who paved their way to an executive position through electoral competition, based on the individual's feelings of being close to the particular groups associated with the leader.

Accordingly, the concept of leader-based partisanship meets relevance in the Indonesian context. Partisanship toward political parties, conceptually known as party identification or Party ID, among Indonesian voters is significantly low. Compared to a global average of $44 \%$, various public opinion polls since Indonesian democratization show a decreasing pattern of Party ID into a point of only around $10 \%$ or less (Liddle \& Mujani, 2007; Mujani et al., 2018). The electoral system, such as open list proportional representation fully applied in Indonesia since 2009, underpins voters' party dealignment; and strong but temporary alignment towards political leaders (Bowler, in Fisher et al., 2017). In short, political leaders play a significant role in determining voters' behaviour in Indonesia (Liddle \& Mujani, 2007).

Scholarship on partisanship or partisan identity has been regarded to have two main arguments: cognitive mobilization and policy polarization (see Heath, in Fisher et al., 2017). Proponents of cognitive mobilization suggest that changes in individual capacity and social mobility affect partisanship. Higher education, loss of information, and rising living standards lead to partisan dealignment (Dalton, 2007, 2014; Norris, 1999). Furthermore, Exemplifying Trump's supporters who believe in that Trump's inauguration in 2017 was crowded by people as the inauguration of Barack Obama in 2009 , Van Bavel \& Pereira (2018, p. 213) suggest that "partisan identities bias a broad range of judgments, even when presented with facts that contradict them". This bias is what political psychology mean when they say partisans suffer from cognitive dissonance. When partisans experience a reality that contradicts their beliefs, they are motivated to reduce the experience of those feelings. Instead of changing their beliefs, partisans even level up their commitment by rationalizing the contradicting reality and inviting others to believe in their judgment (see Van Bavel \& Pereira, 2018).

Meanwhile, theses on policy polarization argue that level of distinction between (or among) parties or political camps generate the extent to which the public align themselves with particular distinct parties or elites. In this regard, the more similar the leaders' platforms, the less partisan the voters. Proponents of these theories contend that political polarization in terms of policy platforms or ideologies drives us to a high level of partisanship (see 
Lupu, 2014; Berglund et al., in Thomassen, 2005). Levendusky (2009) argues that elite polarization in the late 1990s and 2000s had paved the way for the surge of sharpening partisanship for Democrats and Republicans and that observers did not find such clear partisanship in 1970s when both parties displayed heterogenous elites.

Based on those two competing arguments on partisanship, the case of partisan response in a context of crisis management by political leaders, as this paper puts forward, arguably is pertinent to the thesis of policy polarization. The question is how then we measure the extent to which partisan response occurs. In this regard, Samuels \& Zucco (2018) provides a constructive category of partisanship in analysing a Brazilian context. As shown in the Table 1. below, we employ Samuels and Zucco's partisanship spectrum which results in four categories of partisanship: hard-core partisans, positive partisans, negative partisans, and nonpartisans.

Table 1.

Samuels and Zucco's Partisanship Category

\begin{tabular}{|c|c|c|c|}
\hline \multirow[t]{2}{*}{ Yes } & & \multicolumn{2}{|c|}{$\begin{array}{l}\text { Strong identification with in- } \\
\text { group }\end{array}$} \\
\hline & & No & \\
\hline \multirow{2}{*}{$\begin{array}{l}\text { Strong } \\
\text { antipathy } \\
\text { for out-group }\end{array}$} & Yes & $\begin{array}{l}\text { Hard-core } \\
\text { partisans }\end{array}$ & $\begin{array}{l}\text { Negative } \\
\text { partisans }\end{array}$ \\
\hline & No & Positive partisans & Non-partisans \\
\hline
\end{tabular}

Source: Samuels E Zucco (2018)

Regarding the partisanship category in a notion of individual's affections toward a political leader, hard-core partisans are anyone who has strong identification with the political leader's sympathizers (in-group) but at the same time has strong antipathy with other leader(s) and the related sympathizers. Negative partisans mean that individuals do not align themselves with one political leader's supporters but oppose another leader and the supporters. Positive partisan is a reverse concept of the negative one. Nonetheless, anyone who has no alignment with such a group means they are a nonpartisan.

Such a partisanship category and debate on partisanship are getting more viable in social media platforms where people share their thoughts and preferences. Social media platforms such as Facebook and Twitter facilitate interactions among users. Trottier \& Fuchs (2014) suggest that there are three "Cs' inside social media as forms of sociality, namely, cognition, communication, and cooperation, which individuals have certain cognitive features that they use to interact with others so that shared spaces of interaction are created". Furthermore, Kietzmann et al. (2011) use a metaphor of honeycomb that suggests that there are six functional blocks of interdependence in social media, namely, conversations, relationships, sharing, identity, reputation, and presence.

In short, those features provided by all of the users are the source of information, and at the same time, they are active audiences. In other words, a gatekeeper theory, a concept in social groups initially introduced by a social psychologist Kurt Lewin in 1947, does not work in Twitter or probably works in a very different way. The theory refers to individuals who select, reject, or pass certain information to their group or community. In addition, some agree that echo-chamber effects generated through social media's algorithm affect the way people use social media; and in some extent shape people's views, preferences, and belief systems (see, for instance, Jacobson et al., 2016; Lee et al., 2018). Echo-chamber effects occurred when the algorithms manipulate the users only to see content that they frequently act on or favour. People who mostly stop by reading or watching, comment, and share contents they like, they will be fed with similar contents in their future social media activities.

Features and nature of social media platforms generate various kinds of human 
activities never found before, including forms of partisanship expressed in the digital environment. Young adults have been a large chunk of social media users of partisanship so that it is not surprising when they received a significant impact from social media though, at the same time, they are the drivers (see White and Anderson, in Pătruț \& Pătrut, 2014). This occurred in the United Kingdom when a 17-year old student declared his admiration toward the Labour leader in 2015, Ed Miliband, in Twitter and his hashtag \#Milifandom drove a vast number of like-minded sympathizers posting memes about the leader (Penney, 2017). Related to Penney's story, a study by An et al. (2014) finds that what is called 'partisan sharing' occurred among social media users. Though users may be exposed to diverse content, they only act positively, such as share or retweet, to contents affirming their views and beliefs. Sharing features facilitated in Twitter and Facebook pave the way of secondhand political engagement as people produce new contents based on contents produced by a first-hand media source such as television reporting phenomena in place or news reports citing original statements from politicians. To be sure, there are other forms of activities resulted in social media platforms other than partisanship. For instance, this is not surprising when 'clicktivism' has been a term for a new activism in the last decade. The term refers to any kind of activism that is conducted on the internet, especially social media. The main purpose is to gather public attention and support about a content it delivers (Bell, in Harvey, 2014). In this regard, Jeffares (2014) even suggests that hashtag in Twitter has been a lifecycle of policy ideas.

Founded on the conjuncture between polarization argument of partisanship and the nature of social media platforms, this article further addresses empirical notions about how such digital-driven partisanship juxtaposes with a context of crisis, namely, the Covid-19 pandemic in Indonesia. It is idiosyncratic to capture partisanship in social media during a crisis where most people presumably are concerned about their safety, among other things. We, therefore, seek to investigate people's responses to how the most prominent political leaders in Indonesia, the president Joko Widodo and the capital governor Anies Baswedan, respond to the crisis. The two leaders arguably personify two competing camps-pro Jokowi and anti-Jokowi-since the 2014 presidential election (Arifianto, 2019; Aspinall \& Mietzner, 2019; "Polarisation in Indonesia," 2019). “Crisis and leadership are closely intertwined phenomena" (Boin \& Hart, 2003). The following section elaborates briefly on our rationale for picking the two leaders and the camps behind them to probe the partisan response.

\section{Political Polarization in Indonesian Electoral Democracy}

As elaborated later in this section, there are three significant aspects supporting the importance of examining partisanship toward Jokowi and Anies' leadership in the context of the Covid-19 crisis in Indonesia. First, both leaders in the last few months prior to the Covid-19 Pandemic in Indonesia apparently personify two competing camps stemming from the 2014 presidential election. Second, Jokowi and Anies hold executive power in a presidential system at the national and an autonomous administration in the capital setting, respectively. Third, due to those two points, myriad posts and content in social media platforms, especially Twitter, are related to how the two leaders handle the Covid-19 crisis. In this regard, we need to elaborate systematically on the three aspects to give a sense of political and institutional context and rationales of analyzing partisan responses.

Scholarly speaking, Indonesia has been undergoing electoral democracy in the last two decades since the fall of the Suharto 
regime in 1998, with five legislative elections since 1999-and four presidential elections from 2004-to the 2019 general election when legislative and presidential elections were held concurrently for the first time. Among these elections, the last two presidential elections in 2014 and 2019 resulted in political polarization with more than 150 million eligible voters across the archipelago. The rivalry between Jokowi and Prabowo Subianto-later written as Prabowo-in the last two elections has been generating two competing camps, namely, sympathizers of Joko Widodo, an elected president in 2014 and 2019, and a large chunk of people opposing Joko Widodo which most of them cast their votes to Prabowo. Based on the popular vote, Jokowi gained $53.7 \%$ and $55.5 \%$ in 2014 and 2019, respectively. It means that the rest of the votes obviously belong to his rival, Prabowo Subianto in the two elections. This neck-to-neck winning resulted in two competing partisan groups during Jokowi's administration in 2014-2019 and 2019-2024. Later, Prabowo's sympathizers in 2014 and 2019 presidential elections were shocked by Prabowo's alignment with Jokowi's second administration.

Prabowo is the only political figure that paves the way for anti-Jokowi supporters to give their support. In terms of electoral partisanship, there were tangibly conservative Islamist groups among Prabowo's supporters. Exit polls data found that urban-modern Muslims represented are prone to Prabowo's electoral base while rural-traditional Muslim voters are inclined to support Jokowi. Spatial results of 2014 and 2019 presidential elections show that villagers favour the basis of Jokowi's votes, while most of Prabowo supporters are urban inhabitants. In a broad sense, Javanese people residing in central and eastern Java are key supporters for Jokowi, while Sundanese in Western Java to the west of Indonesia, especially Sumatrans are sympathizers for Prabowo. Other provinces are a mix of the two camps. Data of exit polls from various polling institutions in the last two elections show that rural-nationalist and Islam traditionalists were the primary source of Jokowi's voters while urban middle-class and Islam conservatives were a large proportion of Prabowo's voters.

How then did Anies - a close aide of Jokowi for the 2014 presidential race, appointed to be a Ministry of Education but fired two years later in 2015, run for and win the gubernatorial election of Indonesian capital Jakarta - and replace Prabowo to personify the anti-Jokowi camp? Shortly after he was defeated twice in the 2019 electoral combat, Jokowi's rival, Prabowo, ended up in the hands of Jokowi when he and the closest aide in his Gerindra Party, Edy Prabowo, aligned themselves with Jokowi's second administration as the ministry of defense and ministry of the fishery, respectively. Prabowo's shift had confused his loyal sympathizers, especially, groups of Islamist conservatives. In this regard, the result of the gubernatorial election of Jakarta, in 2017 created a critical turnover of anti-Jokowi camps when Prabowo was no longer a personification of anti-Jokowi sentiments.

Similar to the rise of Jokowi when he won the gubernatorial election in Jakarta in 2012. This 'provincial' election in 2017 soon was to gain national attention due to its vast publication around the archipelago. Initially contested by three candidates in a pair, the Jakarta election had been a proxy of three major patrons with their sympathizers. Contending the incumbent Basuki "Ahok" Tjahaja Purnama-Jokowi's vice governor in the 2012 capital electionbacked with Jokowi and PDIP, Agus Harimurti Yudhoyono came to the race as the retired Susilo Bambang Yudhoyono's elder son while Anies Baswedan and his vice gubernatorial candidate Sandiaga Uno were viewed as Prabowo Subianto's protégé. In the first round, Agus was eliminated with only $17 \%$ of share of votes while Ahok and Anies who gained 40 and $43 \%$ electoral supports, respectively, 
passed through the second round. In short, Anies won the heated election with $58 \%$ of the share of votes over Ahok.

To be sure, marches of Islamists in the capital condemned Jokowi and blamed the leader of the prominent Islamic vigilante group FPI. Capturing these waves of Islamist mobilization, Mietzner et al.'s (2018) study shows that Islamist political attitudes increased afterward, driven by what they called entrepreneurs of grievances, namely, a group of Islamic prayers fuelling such mobilization. Street demonstrations and rhetoric against Jokowi-backed incumbent candidate for gubernatorial election of Jakarta capital then amplified throughout the archipelago setting a fire for anti-Jokowi sentiments. While they toppled the incumbent governor of Jakarta Basuki "Ahok" Tjahaja Purnama down, supports of the Islamists and anti-Jokowi voters to Anies are prevalent.

Such electoral polarization and partisan activities that are related to the presidential seat have long been contested by all politicians and their supporters. Though Indonesian presidential experiences were trapped in the coalitional dynamics of the multiparty system (Hanan, 2014; Yuda A. R, 2010), the president constitutionally is the single chief executive who has vast authority for political decisions and public policies, including in a crisis such as the Covid-19 pandemic. In this regard, Jokowi has been portrayed as being a president who effectively exploits the presidential authorities, from public policies to political interests (see Mietzner et al., 2018; Mietzner, 2016). Meanwhile, the partisan shift from Prabowo to Anies affirms theoretical propositions about the short-term effect of leader-based partisanship relative to partybased partisanship. The gubernatorial seat of Indonesian capital is an excellent place to exercise similar authorities to the presidential post due to Jakarta's autonomy (see Law No. 29/2007). Despite lower administration and smaller populations, political leadership in the capital is a showcase for the national audience. Besides, Anies' political rhetoric in many instances shows that he is eager to depict himself not only as a leader holding an executive seat at the provincial level but rather a national leader speaking to all the people in the country. This rhetoric suggests that Anies may desire the top position for any politician's career, namely, the presidential seat.

Briefly, the political trajectory of electoral polarization, personified by Jokowi and Anies, is intertwined with institutional advantage attached in the presidential system and the exclusive autonomy of state capital of Jakarta. The confluence of the electoral dynamics and institutional authorities generate massive supporters for Jokowi and Anies scattered in social media platforms, especially Twitter. The following section explains how these supporters overtly express their partisan response toward the two leaders.

\section{Methods}

First of all, it is essential to capture Twitter data as a proxy for public responses since Indonesia has been one of the ten countries with the most Twitter users by April 2020 (see Clement, 2020). Additionally, data and related sources from Twitter has long been applied by academics to measure and examine public opinion in the last decade (see, for instance, Ausserhofer \& Maireder, 2013; Gruzd \& Mai, 2020; Kwon et al., 2016; Small, 2011). This article, thus, employs Twitter analysis to extract useful patterns and intelligence in online conversations and interactions. It is done by going through activities such as data collection, monitoring, analysis, summarization, and visualization. Fan and Gordon (2014) described social data analysis in three main steps: capture, understand, and present. Capture consists of gathering, preprocessing, and extracting pertinent information and data from various sources. Understand means that we need to 
remove noisy data and perform advanced analytics such as opinion mining, sentiment analysis, topic modeling, social network analysis, and trend analysis. Lastly, present means that we need to summarize and evaluate the findings from the stage of understanding and present the findings.

This research uses Twitter as a data source. By using crawling data from Twitter, this article employs text and social network sources that can be analysed based on Fan and Gordon's social data analysis method. Data is gathered using Twitter API for Python by using two different methods. The first method is by gathering data that contains general keywords related to the issue, and the second one is by gathering tweets from accounts of predefined main actors. Relevant corpus and corpora (keywords) for our NLP analysis are defined as follows: corona, coronavirus, covid19. covid-19, korona, koronavirus.

Focusing on the case of conversations related to Jokowi and Anies as public leaders, we specifically analyse types of Twitter accounts related to the two figures: the personal and affiliated accounts. We do not take into account whether or not both leaders' accounts may be operated by a team for social media management or be managed by the two individuals. All their posts must be under the leaders' knowledge. Predefined main actors are based on Anies' and Jokowi's main official accounts and other official accounts associated with them. Tweets are captured from @jokowi and @PDI_Perjuangan as Jokowi's personal and affiliated accounts, respectively. As such, @aniesbaswedan and @ DKIJakarta are Anies' personal and affiliated accounts. Both Twitter data capture methods are done on the same set of dates between March 2, 2020, and April 17, 2020. March 2 is chosen as the beginning of data capturing because that was the date when the first case of COVID-19 in Indonesia was announced. Initially, both groups of data are being analysed separately to gain initial information.
Each account will be traced to its statements related to the handling and responses of the Covid-19 pandemic posted during the Covid-19 outbreak in March 2020. These statements obviously contain political decisions, positions, and policies taken in response to the pandemic. Afterward, kinds of responses of the corpus and corpora about Covid-19 we define previously towards the two chief executives' leadership and their Twitter accounts are examined through two types of analyses.: NLP and SNA.

Firstly, to get into the more analytical investigation, we employ Natural Language Processing (NLP) in order to dig into the social media user's sentiments, divided largely into positive, neutral, and negative. We then accordingly trace the accounts owning such sentiments based on the groupings and categories. Then, spatial analysis is employed to link and match the maps of sentiments, namely, positive-map and negative-map about the two chief executives. The maps of average electoral supports of the two camps are based on the last two elections in 2019 and 2014 on the basis of the provincial level.

The technical procedures of NLP's data collection and analysis are as follows. Data preprocessing is done by cleaning stop words and text stemming. Both steps are preceded by tokenization or splitting the sentences into words. Stop words are not relevant in observing the main idea of a tweet or sentence; hence, stop word removal is an important step to get cleaner data. Stemming is a process of removing the prefix and suffix of a word to gain the base form of the word itself (Müller \& Guido, 2016). It is done to avoid possible duplicates in finding words that represent the main ideas of the data.

Then, tweets were categorized into three different groups based on mentioned actors: Anies Baswedan and Joko Widodo. Tweets that contain words such as anies, baswedan, abw, gubernur dki and joko, widodo, Jokowi, jkw, presiden are separated 
into two different groups. There is a third group listed as others that does not belong to the first two groups. Sentiment analysis is also practiced by using the Naive-Bayes method. Naïve-Bayes is a classification method that provides efficient analysis with a small batch of the training set (Müller \& Guido, 2016). This gives us flexibility in terms of the number of data acquired and analysed.

Data merger is done towards tweets captured by using general keywords and tweets captured from four predefined main actors. Then, data is filtered in order to clean tweets that are not directly related to Anies and Jokowi based on categorization done before. In this process, tweets from @DKIJakarta and @ PDI_Perjuangan were also filtered out.

Secondly and importantly, Social Network Analysis (SNA) is applied in order to investigate further affiliation among accounts identified through the NLP at the previous stage. This analysis revealed a connection between one account and another one especially, accounts operated by political figures. A final SNA approach is made to assess interconnectivity between data, grouped tendencies, and main actors related to the COVID-19 issue. The SNA is displayed in three different colorcoding methods: sentiment, partisanship, and a combination of sentiment and partisanship. This allows a thorough observation on two different labels (sentiment and partisanship) and its relation to the formed clusters of connection.

Based on categorization and sentiment analysis, charts and social network visualization are projected in order to assess tendencies and possibly further analysis in our data. A descriptive chart is able to project number or ratio of a given parameter effectively (Chen et al., 2008). SNA provides patterns and connectivity insight into social media data (Himelboim, in Matthes et al., 2017). The results brought us to further examine the data by merging and filtering processes.

\section{Results and Discussion Partisan Response in Crisis}

Overall, our data crawling finds a total of 21,095 tweets captured between March $2^{\text {nd }}$, 2020 , to April $17^{\text {th }}, 2020$, that were related to Covid-19. Further, NLP analysis suggests that there are 849 tweets categorized in either Anies or Jokowi topics. In this regard, 284 and 565 of those tweets discussed Anies and Jokowi, respectively. As displayed in Figure 1, we found the highest count of tweets in early April 2020 related to both Jokowi and Anies in response to the crisis of Covid-19. It was publicly known that during this period, there was a debate between the Jokowi administration at the national and Anies' Jakarta administration regarding the authority of quarantine policy in Jakarta (see Setiawan, n.d.).

A closer look at our sentiment analysis finds that Anies and Jokowi received 59.5\% and $70 \%$ of negative responses from Twitter users, respectively. In contrast, positive responses toward both leaders are relatively fewer with $27.9 \%$ and $6.7 \%$ for Jokowi and Anies, respectively. This finding of sentiment analysis and the time series data shows that support and demands toward the ways the two leaders handle the crisis conform to a tendency of partisanship. However, our NLP's spatial data processing finds that there is no reliable provincial-level analysis since there are very few Twitter users who activated location coordinates (latitude and longitude) or declared their place in the Twitter account. As a result, no provinces have representative Twitter users to be analysed further. There are only 34 detected users in Jakarta and 20 users in West Java. The other provinces have less than ten users who activated or declared their location.

Based on the SNA'a visualization displayed in Figure 2 below, we can see two clusters of the Anies category and Jokowi category, both emphasized by the official account of the two political figures. Our data captured primary interaction from both accounts in regard to a 
Figure 1. NLP's Time Series Analysis Comparison Between Jokowi's and Anies' Partisan Response

Tweets per Day (Categorized)

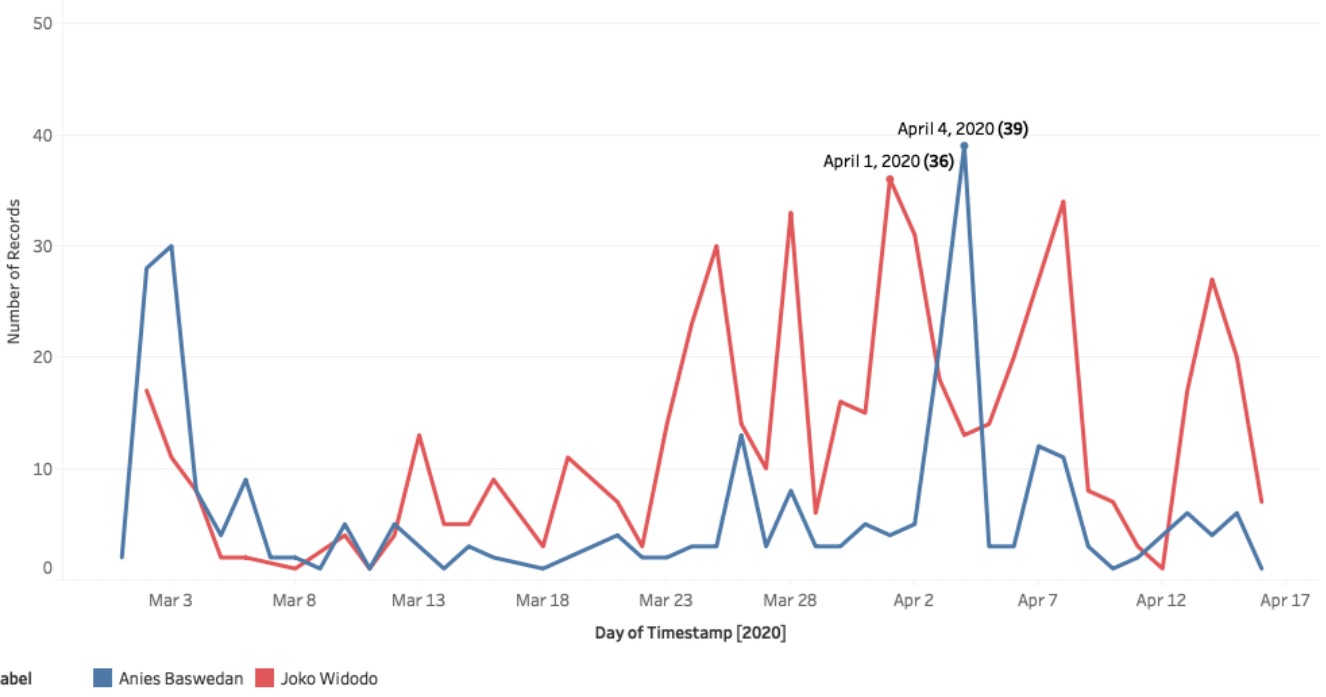

Source: Obtained and analysed from primary data on Twitter, March 2 - April 17, 2020.

Note: Total tweets per day color-coded by topics in which the blue-colored line belongs to Anies Baswedan and red-colored line belongs to Joko Widodo.

separate process, whereas tweets from both accounts were specifically gathered. However, in the other SNA that shows the two-leader connection, we are able to gain insight into how both sides are interconnected. More relatively big clusters talked about Joko Widodo than Anies Baswedan. Meanwhile, @jokowi, Joko Widodo's official Twitter account, is visibly on a distant connection with other nodes, while smaller Joko Widodo clusters spread near smaller Anies Baswedan clusters.

Importantly, statistics of the SNA analysis as shown in the Table 2 below results in a modularity value 0.707 which means close to 1.0 , a maximum value of polarization among the accounts who are connected with the topic. This modularity value indicates a polarized pattern towards two major categories. Furthermore, the network has 6321 nodes that constitute the number of Twitter accounts connected in the topic of Covid-19 in regard to Jokowi and Anies leadership. The edges or connections (line in visualization) among the nodes are 6699 meaning that there a few accounts who have multiple interactions, indicated with the average degree of 1.06. In addition, the value of network diameter is only 4.0, meaning that there are four maximum accounts for content to travel. In short, such a polarization indicated by modularity value is quite high while still depicting close proximity between the clusters and even relatively distant individual nodes.

Table 2.

Statistics of SNA about Public

Responses Toward Jokowi and Anies

Leaderships During Covid-19 Crisis

\begin{tabular}{lc}
\hline \multicolumn{1}{c}{ Attribute } & Value \\
\hline Nodes (accounts) & 6321 \\
Edges (connections) & 6699 \\
Average degree (interactions) & 1.06 \\
Network diameter (longest distance & 4.0 \\
between nodes) & \\
Modularity (heterogeneity/cluster level) & 0.707 \\
\hline
\end{tabular}

Source: Obtained and analysed from primary data on Twitter, March 2 - April 17, 2020. 
Figure 2.

SNA about Public Responses Toward Jokowi and Anies During Covid-19

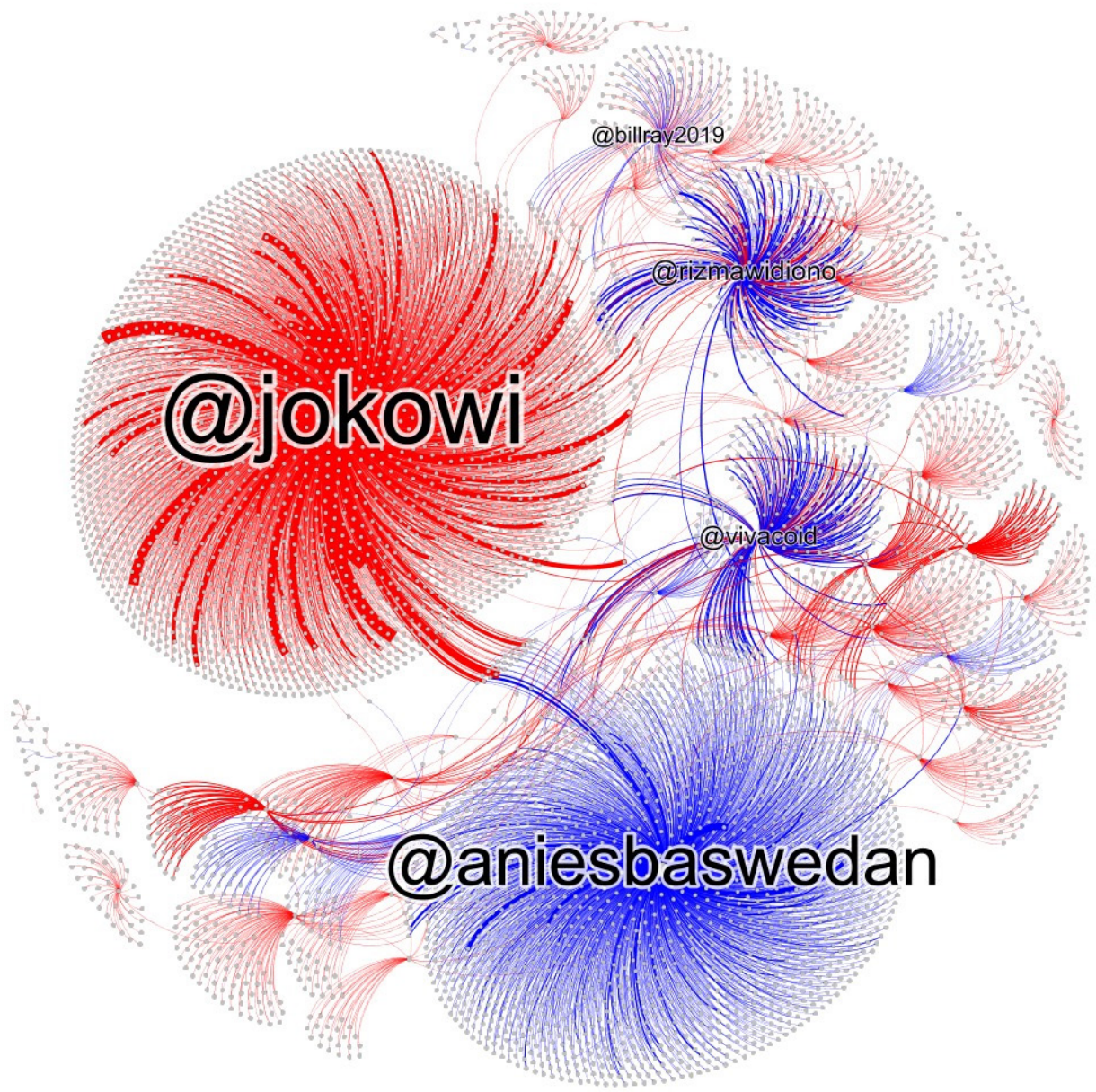

Source: Obtained and analysed from primary data on Twitter, March 2 - April 17, 2020. Note: color-coded network visualization: red for Jokowi and blue for Anies.

A more careful assessment shows that more nodes gravitate towards @aniesbaswedan rather than @jokowi, although more interactions are Jokowi-related. This is described in Table 4 as closeness and betweenness centrality value. Closeness centrality shows how influential a node is due to its proximity or closeness to other nodes with a high amount of connectivity. Meanwhile, betweenness centrality identifies a node that serves as a bridge between one cluster and another (Cherven et al., 2015).

It is shown in betweenness centrality value that the @aniesbaswedan account has more importance in generating connections between one node and another that is not directly interconnected. It is also visible in how different categories and sentiments of connections gravitated more towards the @ aniesbaswedan account. In terms of closeness centrality, non-official accounts tend to have a smaller number which show less proximity to other highly-connected nodes.

Analysis of the SNA statistics above has driven our argument that the extent to which partisanship response is quite high with less than 0.5 means low, around 0.5 is medium, and 1.0 is the highest polarized network referring to the value of modularity while considering 
Table 3.

Network Nodes Closeness, Harmonic Closeness, and Betweenness Centrality Attributes

\begin{tabular}{cccc}
\hline Account & Closeness & $\begin{array}{c}\text { Harmonic } \\
\text { Closeness }\end{array}$ & Betweenness \\
\hline @aniesbaswedan & 1.0 & 1.0 & 18560 \\
@jokowi & 1.0 & 1.0 & 3058 \\
@rizmawidiono & 0.67 & 0.75 & 670 \\
@mas_piyuuu & 0.52 & 0.54 & 451 \\
@vivacoid & 1.0 & 1.0 & 446 \\
\hline
\end{tabular}

Source: Obtained and analysed from primary data on Twitter, March 2 - April 17, 2020.

the number of nodes and edges. A more indepth analysis is needed to investigate further how then the partisan responses work and are distributed between the two competing camps. In this regard, as shown in Figure 3 below, a combined network analysis on sentiments, which are, in turn, indicated as partisanships are presented. To be sure that all tweets coming from @aniesbaswedan and @jokowi are considered neutral. On the sentiment-based network, we can see that only a small portion of connections are polarized between positive or negative. The rest of the edges show neutral tendencies, as also described in Table 5. Many positive and negative sentiment connections about Jokowi are closely tied with connections about Anies or the @aniesbaswedan account. Meanwhile, @jokowi is in its own cluster with several connections also with big clusters of connection related to Anies. This shows that most accounts have single category-sentiment connection, but several others use both figures in showing partisanship tendencies.

Those accounts led all the centrality numbers, most noticeably in degree centrality that simply shows the number of interactions in and out of those accounts to the others. Another official account with high degree centrality number is@vivacoid, which is an online news account. It garnered various interaction in terms of category in sentiment but dominated by
Anies Baswedan related topics. @rizmawidiono garnered more diverse interaction categories and sentiments, whereas @billray2019's interactions are mostly categorized as Aniesnegative and Jokowi-positive. Other than that, many nodes show a singular category and sentiment only.

Table 4.

Network Nodes Degree Centrality

Attributes (Activity of Accounts)

\begin{tabular}{cccc}
\hline Account & $\begin{array}{c}\text { In-Degree } \\
\text { (received } \\
\text { from other } \\
\text { accounts) }\end{array}$ & $\begin{array}{c}\text { Out-Degree } \\
\text { (given } \\
\text { to other } \\
\text { accounts) }\end{array}$ & $\begin{array}{c}\text { Total } \\
\text { Degree }\end{array}$ \\
\hline @jokowi & 2723 & 1 & 2724 \\
@aniesbaswedan & 1777 & 10 & 1787 \\
@rizmawidiono & 275 & 1 & 276 \\
@vivacoid & 223 & 2 & 225 \\
@billray2019 & 128 & 1 & 129 \\
\hline
\end{tabular}

Source: Obtained and analysed from primary data on Twitter, March 2 - April 17, 2020.

Further contextual explanation based on the sentiment network analysis reveals more evident hints regarding partisan response. To be sure, neutral edges (connections) toward Jokowi and Anies are similarly enormous in spite of differences in number, namely, 6242 neutral edges for Jokowi and 3417 neutral edges for Anies. However, a closer look at the number of sentiment networks (edges) connected among the accounts as in Table 4, negative edges toward the two leaders are quite similar with 978 and 983 edges for Jokowi and Anies, respectively. Referring to Samuels and Zucco's (2018) category of partisanship we have presented in the framework section above. This means that there are negative partisans of the two camps. Positive edges, on the other hand, show different results where positive connections toward Jokowi are far more extensive with 1200 positive edges compared to Anies' with only 42 positive edges.

Based on Samuels \& Zucco's (2018) partisanship category, this means that positive 
Figure 3.

A Combined SNA Based on Category and Sentiment about Public Responses Toward Jokowi and Anies During Covid-19

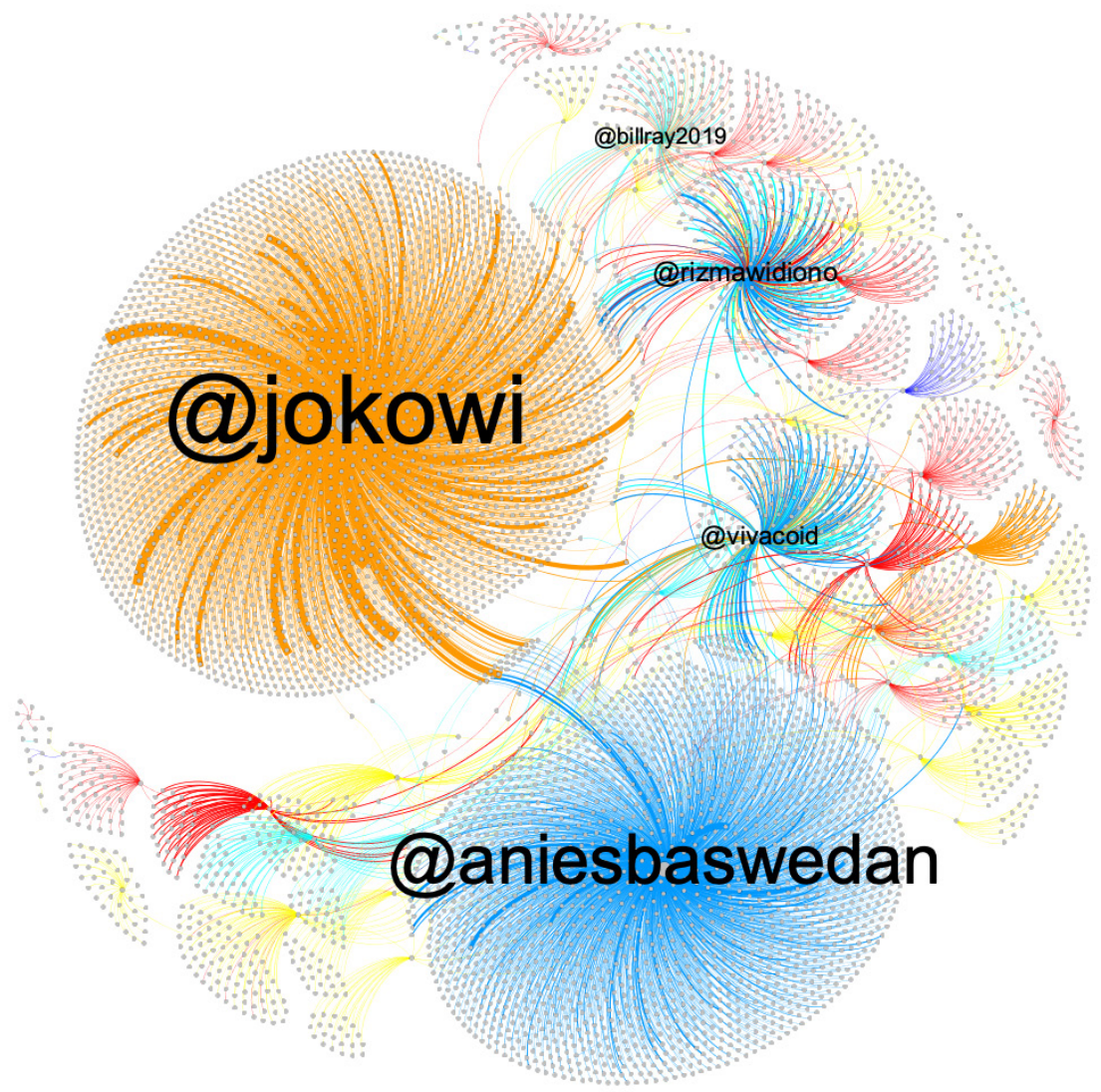

Source: Obtained and analysed from primary data on Twitter, March 2 - April 17, 2020.

Note: Color-coded visualization of the combined SNA by category and sentiment where cyancolored network for Anies-negative sentiment, sky-blue-colored network for Anies-neutral sentiment, and dark-blue-colored network for Anies-positive sentiment; and yellowcolored network for Jokowi-negative sentiment, orange-colored network for Jokowi-neutral sentiment, and red-colored network for Jokowi-positive sentiment.

partisans and negative partisans, with possible hard-core partisans, toward Jokowi circulate and are prevalent during the early period of Covid-19 crisis. This means that partisanship towards Jokowi during the crisis favours Jokowi but dislike (oppose/dislike) the other leader at the same time. Meanwhile, only negative partisans did firmly present for Anies' edges, meaning that partisanships toward Anies are not Anies' sympathizers but only Jokowi's haters. This finding and analysis reflect the electoral polarization in 2014 and
2019 presidential elections, elaborated in the previous section, where the two camps are divided by pro-Jokowi and anti-Jokowi. To be more precise, the latter camp simply personified Prabowo and later Anies as their political preference.

\section{Conclusion}

We have shown some evidence based on Twitter data analysis that polarization contributes to the extent to which partisanship responses circulate in a context of crisis. Our 
Table 5.

Partisan Response Based on Combined SNA with Edge (Connection) Attributes

\begin{tabular}{|c|c|c|c|}
\hline & & \multicolumn{2}{|c|}{ Strong identification with in-group } \\
\hline & & Yes & No \\
\hline \multirow{2}{*}{$\begin{array}{l}\text { Strong } \\
\text { antipathy } \\
\text { for out- } \\
\text { group }\end{array}$} & Yes & $\begin{array}{c}\text { Hard-core } \\
\text { partisans } \\
\text { (numerous } \\
\text { positive and } \\
\text { negative edges) } \\
\text { **Jokowi }\end{array}$ & $\begin{array}{c}\text { Negative } \\
\text { partisans } \\
\text { (only numerous } \\
\text { negative edges) } \\
\text { ***Jokowi (978 } \\
\text { edges) } \\
\text { ***Anies (978 } \\
\text { edges) }\end{array}$ \\
\hline & No & $\begin{array}{c}\text { Positive partisans } \\
\text { (only numerous } \\
\text { positive edges) } \\
* * * \text { Jokowi (1200 } \\
\text { edges) } \\
\text { *Anies (42 edges) }\end{array}$ & $\begin{array}{c}\text { Nonpartisans } \\
\text { (neutral edges) } \\
\text { **Jokowi's 6243 } \\
\text { edges } \\
\text { **Anies' } 3417 \\
\text { edges }\end{array}$ \\
\hline
\end{tabular}

Source: Authors' analysis based on Samuels $\mathcal{E}$ Zucco (2018) partisanship framework. Note: ${ }^{* * *}$ firmly confirmed, ${ }^{* *}$ possibly confirmed, *weakly confirmed.

findings of the natural language process to analyse the pattern of conversation frequencies across time (time series analysis) and categories (clustered analysis) suggest that supports and demand towards the two public figures indicate positive and negative partisanship that replicates previous electoral supports. Meanwhile, our combined social network analysis indicates a high degree of polarization among the thousands of accounts connected with the two leaders in response to the crisis. Extended analyses of the accounts who are the epicentres of the sentiment conversations, either positive or negative about Jokowi and Anies, uncover connections with their past political support. While positive and negative partisans-supporters and haters-towards Jokowi are relatively strong, Anies' positive partisans are firmly weak, but the negative partisans towards him are similar to Jokowi.

These findings contribute to the debate of public response during a context of crisis where people presumably prioritise their safety over other things. Instead, though there are a larger number of people (Twitter users) categorized as nonpartisan, partisan-based response towards the way of how political leaders handle a crisis challenges a rational-economic argument. The rational-economic thesis suggests that people's responses toward policies and leaders are based on their rational evaluation - cost and benefit consideration. Furthermore, our findings conform to polarization thesis of partisanship, arguing that the extent to which partisanship pertains depends on the degree of political/ policy polarization.

Indeed, partisans in a time of crisis signify a high degree of polarization. Yet, it does not mean that partisanship weakens Indonesian democracy. Partisanship, and the polarization that the competing partisan loyalties engendered, nevertheless, affect the ways of how people perceive political realm in a democratic setting. In the case of Jokowi and Anies rivalry in Indonesia, we argue that such partisan bias is temporary since partisanship toward political leaders is believed to be about short-lived loyalties. The breadth and depth of Indonesian elite-based partisan loyalty found in this study, instead of partisan identification with political parties, might be explained by both the weak institutionalization of political parties and the fragile party systems.

Lastly, given the fact that the Covid-19 Pandemic is arguably a prolonged crisis, the data and analysis we have presented obviously may have changed. In addition, scholarly articles agreed that partisanship toward individuals, such as public officials and political elites, are unstable relative to a political party or other ideological institutions. Thus, further investigation for an extended time frame about this topic is needed.

\section{Acknowledgement}

The authors thank Vendi Ardianto Nugroho and Miftah Farid Mahardika, data engineers at the Laboratory of Big Data Analytics, Department of Politics and Government, Universitas Gadjah Mada, for 
their support and efforts. The authors also appreciate Amalinda Savirani, Nanang Indra Kurniawan, and the late Cornelis Lay for their supports in conducting research in the laboratory,

\section{References}

An, J., Quercia, D., \& Crowcroft, J. (2014). Partisan sharing: Facebook evidence and societal consequences. Proceedings of the Second Edition of the ACM Conference on Online Social Networks - COSN '14, 13-24. https://doi.org/10.1145/2660460.2660469

Arifianto, A. R. (2019). What the 2019 Election Says about Indonesian Democracy. Asia Policy, 26(4), 46-53. https://doi. org/10.1353/asp.2019.0045

Aspinall, E., \& Mietzner, M. (2019). Southeast Asia's Troubling Elections: Nondemocratic Pluralism in Indonesia. Journal of Democracy, 30(4), 104-118. https://doi.org/10.1353/jod.2019.0055

Ausserhofer, J., \& Maireder, A. (2013). NATIONAL POLITICS ON TWITTER: Structures and topics of a networked public sphere. Information, Communication $\mathcal{E}$ Society, 16(3), 291-314. https://doi.org/1 0.1080/1369118X.2012.756050

Bartels, L. M. (2000). Partisanship and Voting Behavior, 1952-1996. American Journal of Political Science, 44(1), 35. https://doi. org/10.2307/2669291

Boin, A., \& Hart, P. 't. (2003). Public Leadership in Times of Crisis: Mission Impossible? Public Administration Review, 63(5), 544-553. https://doi.org/10.1111/15406210.00318

Bullock, J. G. (2009). Partisan Bias and the Bayesian Ideal in the Study of Public Opinion. The Journal of Politics, 71(3), 1109-1124. https://doi.org/10.1017/ S0022381609090914

Bullock, J., Gerber, A., Hill, S., \& Huber, G. (2013). Partisan Bias in Factual Beliefs about Politics (No. w19080; p. w19080). National
Bureau of Economic Research. https://doi. org/10.3386/w19080

Burstein, P. (2010). Public Opinion, Public Policy, and Democracy. In K. T. Leicht \& J. C. Jenkins (Eds.), Handbook of Politics (pp. 63-79). Springer New York. https:// doi.org/10.1007/978-0-387-68930-2_4

Chen, C., Härdle, W., \& Unwin, A. (2008). Handbook of Data Visualization. Springer Berlin Heidelberg. https://doi. org/10.1007/978-3-540-33037-0

Cherven, K., TotalBoox, \& TBX. (2015). Mastering Gephi Network Visualization. Packt Publishing. http://www.totalboox. com/book/id-8959988471530263248

Dalton, R. J. (2007). Partisan mobilization, cognitive mobilization and the changing American electorate. Electoral Studies, 26(2), 274-286. https://doi.org/10.1016/j. electstud.2006.04.009

Dalton, R. J. (2014). Citizen politics: Public opinion and political parties in advanced industrial democracies (Sixth edition). SAGE, CQ Press.

Druckman, J. N., Peterson, E., \& Slothuus, R. (2013). How Elite Partisan Polarization Affects Public Opinion Formation. American Political Science Review, 107(1), 57-79. https://doi.org/10.1017/ S0003055412000500

Fan, W., \& Gordon, M. D. (2014). The power of social media analytics. Communications of the ACM, 57(6), 74-81. https://doi. org/10.1145/2602574

Fisher, J., Fieldhouse, E., Franklin, M. N., Gibson, R., Cantijoch, M., \& Wlezien, C. (Eds.). (2017). The Routledge Handbook of Elections, Voting Behaviorand Public Opinion (1st ed.). Routledge. https://doi. org/10.4324/9781315712390

Foster, D. M., \& Palmer, G. (2006). Presidents, Public Opinion, and Diversionary Behavior: The Role of Partisan Support Reconsidered. Foreign Policy Analysis, 2(3), 269-288. https://doi.org/10.1111/j.17438594.2006.00030.x 
Goren, P. (2005). Party Identification and Core Political Values. American Journal of Political Science, 49(4), 881-896. https:// doi.org/10.1111/j.1540-5907.2005.00161.x

Graham, M. H., \& Svolik, M. W. (2020). Democracy in America? Partisanship, Polarization, and the Robustness of Support for Democracy in the United States. American Political Science Review, 114(2), 392-409. https://doi.org/10.1017/ S0003055420000052

Gruzd, A., \& Mai, P. (2020). Going viral: How a single tweet spawned a COVID-19 conspiracy theory on Twitter. Big Data $\mathcal{E}$ Society, 7(2), 205395172093840. https://doi. org/10.1177/2053951720938405

Hanan, D. (2014). Menakar presidensialisme multipartai di Indonesia (Cetakan I). AlMizan

Hanta Yuda A. R. (2010). Presidensialisme setengah hati: Dari dilema ke kompromi. Gramedia Pustaka Utama.

Harvey, K. (2014). Encyclopedia of Social Media and Politics. SAGE Publications, Inc. https://doi.org/10.4135/9781452244723

Hosseini, P., Hosseini, P., \& Broniatowski, D. A. (2020). Content analysis of Persian/ Farsi Tweets during COVID-19 pandemic in Iran using NLP. ArXiv:2005.08400 [Cs]. http://arxiv.org/abs/2005.08400

Jacobson, S., Myung, E., \& Johnson, S. L. (2016). Open media or echo chamber: The use of links in audience discussions on the Facebook Pages of partisan news organizations. Information, Communication $\mathcal{E}$ Society, 19(7), 875-891. https://doi.org/1 0.1080/1369118X.2015.1064461

Jeffares, S. (2014). Interpreting Hashtag Politics. Palgrave Macmillan UK. https://doi. org/10.1057/9781137357748

Kietzmann, J. H., Hermkens, K., McCarthy, I. P., \& Silvestre, B. S. (2011). Social media? Get serious! Understanding the functional building blocks of social media. Business
Horizons, 54(3), 241-251. https://doi. org/10.1016/j.bushor.2011.01.005

Kwon, K. H., Bang, C. C., Egnoto, M., \& Raghav Rao, H. (2016). Social media rumors as improvised public opinion: Semantic network analyses of twitter discourses during Korean saber rattling 2013. Asian Journal of Communication, 26(3), 201-222. https://doi.org/10.1080/01292986.2015.1 130157

Lee, P. S. N., So, C. Y. K., Lee, F., Leung, L., \& Chan, M. (2018). Social media and political partisanship -A subaltern public sphere's role in democracy. Telematics and Informatics, 35(7), 1949-1957. https://doi. org/10.1016/j.tele.2018.06.007

Levendusky, M. (2009). The Partisan Sort: How Liberals Became Democrats and Conservatives Became Republicans. University of Chicago Press. https://doi.org/10.7208/ chicago/9780226473673.001.0001

Liddle, R. W., \& Mujani, S. (2007). Leadership, Party, and Religion: Explaining Voting Behavior in Indonesia. Comparative Political Studies, 40(7), 832-857. https:// doi.org/10.1177/0010414006292113

Lupu, N. (2014). Brand Dilution and the Breakdown of Political Parties in Latin America. World Politics, 66(4), 561-602. https://doi.org/10.1017/ S0043887114000197

Matthes, J., Davis, C. S., \& Potter, R. F. (Eds.). (2017). The International Encyclopedia of Communication Research Methods (1st ed.). Wiley. https://doi. org/10.1002/9781118901731

Mietzner, M. (2020). Authoritarian innovations in Indonesia: Electoral narrowing, identity politics and executive illiberalism. Democratization, 27(6), 1021-1036. https:// doi.org/10.1080/13510347.2019.1704266

Mietzner, M., \& Associate Professor, Coral Bell School of Asia Pacific Affairs, College of Asia and the Pacific, Australian National 
University, Canberra; and Visiting Research Scholar, Center for Southeast Asian Studies, Kyoto University, Kyoto. (2016). Coercing Loyalty: Coalitional Presidentialism and Party Politics in Jokowi's Indonesia. Contemporary Southeast Asia, 38(2), 209-232. https://doi. org/10.1355/cs38-2b

Mietzner, M., Muhtadi, B., \& Halida, R. (2018). Entrepreneurs of Grievance: Drivers and Effects of Indonesia's Islamist Mobilization. Bijdragen Tot de Taal-, Land- En Volkenkunde / Journal of the Humanities and Social Sciences of Southeast Asia, 174(2-3), 159-187. https:// doi.org/10.1163/22134379-17402026

Mujani, S., Liddle, R. W., \& Ambardi, K. (2018). Voting Behavior in Indonesia since Democratization: Critical Democrats (1st ed.). Cambridge University Press. https:// doi.org/10.1017/9781108377836

Müller, A. C., \& Guido, S. (2016). Introduction to machine learning with Python: A guide for data scientists (First edition). O'Reilly Media, Inc.

Norris, P. (1999). Critical Citizens. Oxford University Press. https://doi. org/10.1093/0198295685.001.0001

Odegard, P. H. (1960). The American Voter. Angus Campbell, Philip E. Converse, Warren E. Miller, and Donald E. Stokes. Wiley, New York, 1960. 573 pp. \$8.50. Science, 132(3420), 138-140. https://doi. org/10.1126/science.132.3420.138

Page, B. I., \& Shapiro, R. Y. (1983). Effects of Public Opinion on Policy. American Political Science Review, 77(1), 175-190. https://doi.org/10.2307/1956018

Parahita, G. D. (2019). Voters (Dis)-Believing Digital Political Disinformation in Gubernatorial Election of DKI Jakarta 2016-2017. Jurnal Ilmu Sosial Dan Ilmu Politik, 22(2), 127. https://doi.org/10.22146/ jsp.33736
Pătruț, B., \& Pătruț, M. (Eds.). (2014). Social Media in Politics: Case Studies on the Political Power of Social Media (Vol. 13). Springer International Publishing. https://doi. org/10.1007/978-3-319-04666-2

Penney, J. (2017). The Citizen Marketer (Vol. 1). Oxford University Press. https://doi.org/10.1093/acprof:o so/9780190658052.001.0001

Polarisation in Indonesia: What if perception is reality? (2019, April 16). New Mandala. https://www.new mandala.org/howpolarised-is-indonesia/

Reid, M. M., Jarrett Renshaw, Tim. (2020, April 22). How Trump allies have organized and promoted anti-lockdown protests. Reuters. https://www.reuters.com/article/ us-health-coronavirus-trump-protestsidUSKCN2233ES

Samuels, D. J., \& Zucco, C. (2018). Partisans, Antipartisans, and Nonpartisans: Voting Behavior in Brazil (1st ed.). Cambridge University Press. https://doi. org/10.1017/9781108553742

Setiawan, R. (n.d.). Anies akan Surati Menkes Terawan Minta Jakarta Segera Tetapkan PSBB. tirto.id. Retrieved November 8, 2020, from https://tirto.id/anies-akansurati-menkes-terawan-minta-jakartasegera-tetapkan-psbb-eKqG

Small, T. A. (2011). WHAT THE HASHTAG?: A content analysis of Canadian politics on Twitter. Information, Communication $\mathcal{E}$ Society, 14(6), 872-895. https://doi.org/10. 1080/1369118X.2011.554572

Soroka, S. N., \& Wlezien, C. (2005). OpinionPolicy Dynamics: Public Preferences and Public Expenditure in the United Kingdom. British Journal of Political Science, 35(4), 665-689. https://doi.org/10.1017/ S0007123405000347

Thomassen, J. (2005). The European Voter. Oxford University Press. https://doi. org/10.1093/0199273219.001.0001 
Trottier, D., \& Fuchs, C. (Eds.). (2014). Social media, politics and the state: Protests, revolutions, riots, crime and policing in the age of Facebook, Twitter and YouTube. Routledge.

Van Bavel, J. J., \& Pereira, A. (2018). The Partisan Brain: An Identity-Based Model of Political Belief. Trends in Cognitive Sciences, 22(3), 213-224. https://doi. org/10.1016/j.tics.2018.01.004

Wlezien, C. (2004). Patterns of Representation: Dynamics of Public Preferences and Policy. The Journal of Politics, 66(1), 1-24. https:// doi.org/10.1046/j.1468-2508.2004.00139.x 